\title{
ПРОЦЕСУАЛЬНІ ПІДСТАВИ ЗАЛУЧЕННЯ ЗАХИСНИКА У КРИМІНАЛЬНОМУ ПРОВАДЖЕННІ
}

\author{
МАРТОВИЦЬКА Олена Василівна - кандидат юридичних наук, доцент \\ кафедри кримінального процесу та організації досудового слідства Харківського \\ національного університету внутрішніх справ
}

DOI:10.32782/LAW.2019.3.13

УДК 343.121.4(477)

В статье вълполнено теоретическое исследование законодательньх, научных и прикладных вопросов относительно привлечения защитника в уголовном производстве. При этом проанализировано различнъие научные школьг и позиции отдельньих ученъгх относительно исследованного направления и материальи правоприменительной практики, по которьм въикказанъ научнъие взглядъ автора. Внесенъ конкретные предложения по усовершенствованию отдельных положений уголовного процессуального законодательства Украинъ и правоприменительной деятельности по изученныл вопросам.

Ключевые слова: досудебное расследование, уголовньий процесс, право на защиту, защитник, правовая помощь, статус, положение, закон, процессуальнье правоотношения, участник, фбункиия, научная позищия, следователь, прокурор, следственнъий судья, права и свободъ .

Постановка проблеми

3 дослідження встановлено, що після прийняття у 2012 році чинного КПК України до нього було внесено ряд змін і доповнень. Зокрема, внесено зміни й до ст. 59 Конституції України щодо окремих питань, піднятих автором у дослідженні, в тому числі, що кожен має право на професійну правничу допомогу, замість права на правову допомогу [1]. У той же час, у чинний КПК України не внесено відповідних змін ні у ч. 1, 2 та 3ст. 20 КПК України,де ведеться мова про надання правової або кваліфікованої правової допомоги [2]. Крім цього, продовжується дискусія з питань процесуального залучення захисника у кримінальному провадженні.Дискусії сприяють й наявні неузгодженості між чинним КПК України і Законом України «Про адвокатуру та адвокатську діяльність»[3], у яких також закріплено надання правової допомоги, а не правничої. У випадках, окремо передбачених законом, така допомога надається безоплатно. Вказана новела, що внесена в Основний закон, підлягає переосмисленню та проведенню відповідних досліджень у порівнянні з положеннями чинного КПК України як у теоретичному, так і у прикладному напрямі.

Аналіз останніх досліджень і публікацій

За останні роки науковці досить плідно досліджували питання залучення захисника для забезпечення права на захист як окремих учасників як кримінального провадження, так і з інших теоретичних i прикладних питань забезпечення та реалізації правової і правничої допомоги. Ці питання розглядались у роботах учених, зокрема: С.С. Абламського, О.М. Бандурки, Ю.В. Бауліна, В.П. Бож'єва, В.В. Борисова, Т.В. Варфоломеєвої, Б.А. Ващука, В.І. Галагана, I.М. Гальперіна, А.А. Гарбовського, А.В. Головка, В.Г. Гончаренка, Ю.М. Грошевого, М.І. Гошовського, С. М. Гусарова, Є.В. Діденка, В.О. Дубрівного, М.В. Духовського, Я.П. Зейкана, О.А. Калганова, О.В. Капліної, Г.К. Кожевнікова, А.Ф. Коні, 


\section{Кримінальне право, кримінальний процес та криміналістика}

В.В. Лисенка, А.Д. Кокорева, Н.І. Клименка, О.П. учинської, О.О. Кочури, В.З. Аукашевича, Е.Д. Аук'янчикова, В.Т. Маляренка, М.М. Михеєнка, Т.В. Омельченка, В.Т. Нора, О.В. Панчука, М.А. Погорецького, Т.I. Присяжнюка, В.Д. Пчолкіна, В.М. Савицького, М.В. Сенаторова, M.C. Строговича, B.M. Тертишника, А.Д. Удалової, І.Я. Фойницького, Т.Г. Фоміної, П.В. Цимбала, В.П. Шибіки, О.Г. Шило, М.Е. Шумили, В.С. Юрченка, О.О. Юхна, М.О. Юхна, Ю.П. Яновича та інших. Зокрема, на рівні кандидатської дисертації ці питання досліджено С.С. Абламським «Захист прав і законних інтересів потерпілого у кримінальному провадженні» (2014р.); Д.Ю. Кавуна «Кримінальний процесуальний механізм забезпечення прав потерпілого (фізичної особи) у досудовому розслідуванні» (2016 р.), по окремих напрямах: O.О. Сольонової «Показання потерпілого як джерело доказів у кримінальному провадженні» (2018 р.); на рівні монографії «Захисник як учасник кримінального провадження» ці питання досліджувались Ерохіним В.В. і Юхно О.О. (2018р.) та фрагментарно досліджували й інші вчені. У той же час, за час дії чинного КПК України до нього внесено понад 570 доповнень і змін, які не знайшли свого відображення в наукових вивченнях i дослідженнях та потребують окремого висвітлення, зокрема $з$ питань дотримання пропорційності прав захисникаадвоката підозрюваного, обвинуваченого i захисника-представника потерпілого та щодо захисту прав інших учасників кримінального провадження.

\section{Формування цілей}

Враховуючи нагальну потребу сьогодення щодо удосконалення захисту прав учасників кримінального провадження як зі сторони захисту, так і сторони обвинувачення, неузгодженість між собою чинних законів 3 цих питань, зауваження теоретичного i прикладного характеру, недоліки наявного законодавства та проблемні питання при правозастосуванні, наявну дискусію з піднятого питання, виникає потреба і завдання у теоретичному дослідженні вказаних питань і напрацювання відповідних пропозицій та рекомендації щодо удосконалення чинного кримінального процесуального законодавства України $з$ цього напряму, враховуючи міжнародне законодавство і рішення ЕСП $А$.

\section{Виклад основного матеріалу}

Відповідно до положень Конституції України і КПК України,забезпечення права на професійну правничу допомогу є однією iз важливих гарантій забезпечення прав, свобод і законних інтересів учасників кримінального провадження, справедливого судового розгляду з тим, щоб кожний, хто вчинив кримінальне правопорушення, був притягнутий до відповідальності, і жодна особа не була піддана необгрунтованому процесуальному примусу. Суттєвий вплив на реалізацію вказаного в Україні мають міжнародні правові стандарти та договори. Так, зокрема, основні принципи, що стосуються ролі юристів у кримінальному процесі, прийняті Конгресом ООН 27 серпня-7 вересня 1990 року, передбачають, що кожна людина має право звернутися до будь-якого юриста за правовою допомогою щодо захисту і відстоювання своїх прав і захисту їх на всіх стадіях кримінального судочинства [4]. У свою чергу, Міжнародний пакт про громадянські та політичні права у статті 14 проголошує право кожної людини в разі його звинувачення у вчиненні протиправної дії захищати себе особисто або використовувати правову допомогу захисника[5].Крім того, ч. 3 ст. 6 Конвенції про захист прав людини і основних свобод вказує, що кожен підозрюваний, обвинувачений у вчиненні кримінального правопорушення, має щонайменше такі права, зокрема, захищати себе особисто або безпосередньо через правову допомогу захисника, вибраного на свій розсуд[6].До прийняття чинного КПК України 3 цих питань В.Т.Маляренко зазначав, що особа, яка підозрюється та обвинувачується державою у вчиненні злочину, перебуває у значно гіршому становищі, оскільки не має тих можливостей для захисту, якими наділена держава для обвинувачення [7,с. 134], що ми підтримуємо, однак, на нашу думку,залучення до участі захисника у кримінальне провадження виступає однією із гарантій реалізації права на професійну 
правничу допомогу, зокрема, що гарантовано Конституцією України.

У свою чергу, чинний КПК України закріпив концептуально нове i прогресивне положення, а саме: відповідно до ст. 20 КПК України та змін до нього 3 питань запровадження кримінальних проступків,підозрюваному, обвинуваченому, виправданому, засудженому забезпечується право на захист.Особа, яка провадить дізнання по кримінальних проступках, а слідчий, прокурор у кримінальних провадженнях про злочин, а також слідчий суддя і суд зобов'язані роз'яснити підозрюваному, обвинуваченому його права та забезпечити право на кваліфіковану правову допомогу,зробити та видати у письмовому вигляді витяг його прав і обов'язків, про що скласти протокол, а також надати їм можливість захищатися встановленими законом засобами від моменту затримання чи повідомлення про підозру у вчиненні кримінального правопорушення. Невиконання таких вимог $є$ істотним порушенням закону, що тягне за собою скасування прийнятих рішень, винесення виправдовувального вироку у тих випадках, коли обвинувальний акт був направлений до суду. Це пояснюється тим, що позбавлення чи обмеження у наданні зазначених прав перешкоджає всебічному, повному та неупередженому досудовому розслідуванню й судовому розгляду обставин кримінального провадження, встановленню об'єктивної істини, а відповідно й прийняттю законних та обгрунтованих рішень. Доречно 3 цього приводу зазначивА. Мужиновський та інші вчені, що «...інститут захисту є гарантією встановлення істини та дотримання громадянських прав та свобод» [8,с. 25], що ми підтримуємо.Слід дослідити термінологічне визначення окремих понять у зв' язку зі зміною положень у чинному КПК України. Так, раніше, зокрема, у ст. 47 КПК України 1960 р. використовувались поняття «запрошення захисника» $\mathrm{i}$ «призначення захисника». На той час запрошення захисника здійснювалось безпосередньо підозрюваним, обвинуваченим, підсудним чи засудженим, їх законними представниками, а також іншими особами за проханням чи їх згодою. У свою чергу, призначення за- хисника на той час здійснювалось особою, яка проводила дізнання, слідчим або судом. Згідно з чинним КПК України вказані поняття замінено на «залучення захисника», що регламентовано параграфом 3 третьої глави «Сторона захисту». Фактично законодавець в одне поняття вклав два різнопланових поняття, яке за своєю суттю визначає як реалізацію права підозрюваного, обвинуваченого на захист за допомогою захисникаадвоката, так і обов'язок слідчого, прокурора, слідчого судді чи суду в разі необхідності залучити захисника. 3 одного боку таке залучення захисника підозрюваним, обвинуваченим, їх законними представниками, а також іншими особами за їх проханням чи за згодою підозрюваного, обвинуваченого до участі у кримінальному провадженні, а 3 іншого - це залучення за призначенням, що у разі потреби забезпечується слідчим, прокурором, слідчим суддею чи судом для захисту у випадках і у порядку, передбаченому статтями 49 та 53 КПК України. У той же час, у ч. 2 ст. 53 чинного КПК України законодавець використовує поняття «запрошення захисника», випадки та процесуальний порядок якого зовсім не регламентовано. У зв’язку з цим, на нашу думку, доцільно внести зміни та доповнення до КПК України, зокрема:у ч. 1 ст. 48 КПК України слід закріпити про «запрошення захисника», яке здійснюється підозрюваним, обвинуваченим, їх законними представниками, а також іншими особами за запрошенням або проханням чи згодою підозрюваного, обвинуваченого до участі у кримінальному провадженні. У свою чергу, в ч. 2 ст. 48 КПКУкраїни слід закріпити «залучення захисника», оскільки у такому випадку слідчий, прокурор виносить постанову, а слідчий суддя та суд постановляють ухвалу.

Участь захисника у кримінальному провадженні має бути забезпечена у таких випадках: 1) відповідно до вимог ст. 52 КПК України це повинно бути обов'язковим, якщо підозрюваний, обвинувачений не залучив захисника; 2) підозрюваний, обвинувачений заявив клопотання про залучення захисника, але за відсутністю чи недостатністю коштів, а також 3 інших об'єктивних причин не може його залучити самостійно; 


\section{Кримінальне право, кримінальний процес та криміналістика}

3) якщо слідчий, прокурор, слідчий суддя чи суд вирішить, що КПК України та обставини кримінального провадження вимагають участі захисника, а підозрюваний, обвинувачений не залучив його.

Перелік випадків, у яких захисник залучається за призначенням, не 6 вичерпним, адже ч. 1 ст. 49 КПК України містить також положення про те, що захисник може бути залучений слідчим, прокурором, слідчим суддею чи судом в інших випадках, передбачених законом, що регулює надання безоплатної правової допомоги. У зв’язку 3 цим, А. Титов зазначав, що підозрюваному, обвинуваченому повинна бути надана реальна можливість захищатися встановленими законом засобами і способами від пред'явленого йому обвинувачення. При цьому, вчений посилався на позицію німецьких правників Х. Аютера і Ф. Вольфа, згідно 3 якою, однією із найважливіших правових гарантій здійснення права підозрюваного, обвинуваченого на захист є встановлений законом обов'язок органів, які ведуть судочинство, всебічно і об' єктивно досліджувати справу, забезпечити обвинуваченому реалізацію його права на захист [9, с. 8], що ми підтримуємо.

3 метою реалізації правової допомоги у захисника є право брати участь у проведенні допиту та інших процесуальних діях, що проводяться за участю підозрюваного, обвинуваченого. Забезпеченню цього права сприяе обов'язок слідчого, прокурора, слідчого судді, суду завчасно попередити захисника про проведення відповідної процесуальної дії (ст. 48 КПК України). Цей строк має бути достатнім і реальним для того, щоб захисник мав змогу з'явитися для участі у слідчій (розшуковій) дії або повідомити заздалегідь про неможливість явки і причини, що не можуть цьому сприяти. Обов'язок захисника щодо своєчасного повідомлення слідчого, прокурора, слідчого судді, суду 3 цих питань здійснюється у порядку, встановленому положеннями ч. 2 статті 47 КПК України.

Для захисту прав і законних інтересів підозрюваного набуває значення новела щодо реалізації права захисника до першого допиту підозрюваного мати 3 ним конфіден- ційне побачення без дозволу слідчого, прокурора, суду, а після першого допиту такі ж побачення, без обмеження їх кількості та тривалості. Залучення захисника до участі у кримінальному провадженні на початкових етапах досудового розслідування є процесуальною гарантією і сприянням ефективної реалізації прав підозрюваного та обвинуваченого, а також створює додаткові умови для швидкого, повного та неупередженого розслідування, зокрема забезпечення засад верховенства права,законності тощо.

Закріплення у КПК України положень щодо заборони на прослуховування розмов захисника із підозрюваним і обвинуваченим позичено 3 прецедентної практики Европейського суду.Також заслуговує уваги оцінка $6 С П \lambda$ питання відносно співвідношення вимог щодо ефективності та якості реалізації права на правову допомогу за призначенням відповідно до вимог ст. 6 Конвенції. Так, у рішенні «С. проти Швейцарії» $\mathrm{ECП} \lambda$ вказав, що «...право обвинуваченого спілкуватись зі своїм адвокатом поза межами чутності третьої особи, є однією з головних вимог справедливого судового процесу у демократичному суспільстві і випливає з положень п. 3 ст. 6 Конвенції. Якщо адвокат не має можливості зв'язатися зі своїм клієнтом і отримати від нього конфіденційні інструкції, без такого нагляду, то його допомога значною мірою втрачає свою корисливість, у той час як вказана Конвенція покликана гарантувати право, що має як практичний, так і дійовий характер».Наявність таких новел у законодавстві свідчить про його наближення до європейських правових стандартів із забезпечення права на правничу професійну допомогу на стадії досудового розслідування. Однак, відсутність дієвого процесуального механізму реалізації вказаного правового припису ускладнюе його прикладну реалізацію.

Відповідно до положень ч. 3 ст. 46 КПК України кількість захисників одного обвинуваченого обмежується до п'яти. У зв'язку з цим слідчий, прокурор, суд і суддя зобов'язані забезпечити право вільного вибору кількості і персонального складу захисників. У той же час, на нашу думку, у КПК України не повинна бути обмежена кількість 
адвокатів до п'яти, що підлягає законодавчому уточненню та закріпленню. У свою чергу, характер обставин, що становлять зміст підстав щодо залучення захисника, є різним, але спільним для них $є$ те, що вони свідчать про неможливість забезпечення захисту законних інтересів підозрюваного, обвинуваченого без участі захисника. Так, рішення про залучення захисника за призначенням має бути визначено слідчим, прокурором у постанові, а слідчим суддею, судом - в ухвалі. Вимоги щодо форми та змісту такої постанови закріплено ст. 110 КПК України. Вказані рішення повинні відповідати загальним вимогам, передбаченим статтями 370, 372 КПК України. Частина 3 ст. 49 КПК України наголошує на обов'язковості виконання постанови, ухвали про доручення призначення захисника та встановлюе строк іï направлення (надіслання) до відповідного органу (установи), уповноваженого законом для надання безоплатної правової допомоги та іï виконання. Законодавець також використовує термін «негайно», що означає виконання відразу ж після прийняття, отримання рішення (постанови, ухвали) про призначення захисника. Невиконання, неналежне або несвоєчасне виконання постанови (ухвали) про доручення призначення адвоката тягнуть відповідальність, встановлену законом,і такі дії з боку адвоката можуть становити склад дисциплінарного проступку. Оплата праці захисника у разі його участі у кримінальному провадженні за призначенням проводиться за рахунок держави у порядку та розмірах, встановлених і затверджених відповідною Постановою Кабінету Міністрів України.

У чинному КПК України інститут реалізації права на правову допомогу удосконалено, зокрема, у п. 13 ч. 1 ст. 7 КПК України «Загальні засади кримінального провадження» закріплено засаду забезпечення права на захист. Однак, деякі положення потребують свого уточнення та доповнення. Так, на думку С.С. Абламського, статтю 20 КПК України «Забезпечення права на захист» доцільно доповнити, зокрема, крім реалізації права на правову допомогу підозрюваним, обвинуваченим, виправданим, засудженим, таке право закріпити за потер- пілим, свідком, експертом, перекладачем, цивільним позивачем, цивільним відповідачем та іншими учасниками кримінального провадження [10, с. 48-49], що ми підтримуємо. Як доречно зазначила Г. Власова, що із введенням КПК України 2012 року наша країна отримала важливий елемент сучасної правової держави - змагальну процедуру кримінального процесу, в якому захист має такі ж самі права, що й обвинувачення [11, с. 31]. У свою чергу, П. Маланчук зазначив, що КПК України передбачає створення рівних можливостей для кожної із сторін у кримінальному процесі та реальне впровадження у кримінальне судочинство принципу змагальності, згідно з чим результат розгляду судом конкретного випадку притягнення особи до кримінальної відповідальності залежатиме виключно від обгрунтованості позиції сторін. КПК України передбачає реалізацію засади змагальності судочинства шляхом запровадження нового порядку, згідно з яким суд повинен грунтувати свої висновки виключно на тих показаннях, які він безпосередньо отримав від сторін кримінального провадження у судовому засіданні або які були надані слідчому судді у судовому засіданні під час досудового розслідування [12, с. 51-52]. 3 приводу цього, ЕСП $\lambda$ у своїх рішеннях неодноразово зазначав, що визначення допустимості доказів є прерогативою національного права i, за загальним правилом, саме національні суди уповноважені оцінювати надані їм докази (параграф 34 рішення у справі «Тейксейр де Кастро проти Португалії» від 9 червня 1998 року, параграф 54 рішення у справі «Шабельник проти України» від 19 лютого 2009 року [13]), а сам порядок збирання доказів, передбачений національним процесом, має відповідати основним правам, визнаним Конвенцією про захист прав людини та основоположних свобод, а саме: на свободу, особисту недоторканність, на повагу до приватного і сімейного життя, таємницю кореспонденції, на недоторканність житла (статті 5, 8 Конвенції) тощо. Наприклад, докази можуть не відповідати вимогам допустимості, якщо вони були одержані з порушеннями, пов'язаними із незаконним обмеженням основоположних прав і свобод людини, за- 


\section{Кримінальне право, кримінальний процес та криміналістика}

кріплених у Конституції України. 3 введенням чинного КПК України відбулась трансформація форми кримінального судочинства $з$ розшукової на змагальну.

На нашу думку, згідно з результатами дослідження встановлено дисбаланс між об'ємом прав у потерпілого та підозрюваного і обвинуваченого. Так, за КПК України права потерпілого закріплено у п'яти статтях, а підозрюваного, обвинуваченого у п'ятнадцяти статтях. У зв'язку з цим, Г.А. Васильєв зазначив: «...коли ми говоримо про демократичність щодо прав особи, то не можна однобічно ставитися до цієї справи - пом'якшуючи норми щодо затриманого, підозрюваного, обвинуваченого і не посилюючи заходи захисту прав потерпілого, який часто виявляється беззахисним і піс^я розкриття злочину» $[14$, с. 6$]$, що ми підтримуємо.Після виникнення кримінальних процесуальних відносин відбувається конкретизація та реалізація конституційних правовідносин. Після цього вирішуються питання, пов'язані із залученням захисника до участі у кримінальному провадженні, і лише після цього виникають кримінальні процесуальні правовідносини між адвокатом і органами досудового розслідування, тоді як правовідносини між клієнтом і адвокатом не припинялися і трансформуються у кримінально процесуальні. У цьому випадку право на правничу допомогу перевтілюється в право на захист від обвинувачення чи захисту прав. Виходячи із цього, необхідно визначати початковий момент адвокатського імунітету, яким $є$ укладання договору про надання правової допомоги. Слідчий, прокурор, слідчий суддя чи суд мають право залучити захисника для проведення окремої процесуальної дії. Таке залучення допускається лише виключно у невідкладних випадках.Невідкладні випадки можуть мати місце при: 1) потребі у проведенні невідкладної процесуальної дії за участю захисника, а завчасно повідомлений захисник не може прибути для участі у проведенні процесуальної дії чи забезпечити участь іншого захисника; 2) якщо підозрюваний, обвинувачений виявив бажання, але ще не встиг залучити захисника; 3) прибуття обраного захисника неможливо. Крім цього, під такими випадками слід розуміти процесуальні дії, зволікання з провадженням яких може викликати негативні наслідки, зокрема й правові, для підзахисного.

у той же час, надаючи можливість підозрюваному, обвинуваченому відмовитися від участі захисника у провадженні, закон разом 3 тим встановлює, що їх відмова не може бути прийнята, зокрема у випадках, коли участь захисника $є$ обов'язковою.3 приводу цього, Пленум Верховного Суду України у Постанові від 24 жовтня 2003 р. № 8 «Про застосування законодавства, яке забезпечує право на захист у кримінальному судочинстві» [15] визначив, що «відмова від захисника можлива на будь-якій стадії процесу,але за ініціативою підсудного. Вирішуючи питання про прийняття такої відмови, суд має з'ясувати, чи не є вона вимушеною (наприклад, у зв'язку з неявкою захисника в судове засідання) і як у подальшому такі особи здійснюватимуть свій захист - самостійно чи за допомогою іншого захисника. Установивши вимушеність відмови, суд вживає передбачені законом заходи щодо забезпечення участі захисника у провадженні.При відмові від конкретного захисника цим особам має бути надана реальна можливість його заміни іншим захисником». Утім зазначені умови не вичерпують усіх передбачених законом вимог до забезпечення права на захист. У випадку прояву явного некваліфікованого захисту або подання обгрунтованої скарги підзахисного на дії призначеного йому захисника, на думку О.А. Кучинської, слідчий, прокурор, суддя або суд зобов'язаний призначити підозрюваному, обвинуваченому іншого захисника [16, с. 4-5], що ми підтримуємо.Новелою для КПК України є положення про те, що таке правило використовується з урахуванням рішень ЄСП $А$. Наприклад, у рішенні ЄСПЛ «Яременко проти України» (2008р.) [17] відмова від захисника, зроблена обвинуваченим без участі захисника під тиском на той час працівників міліції,що розцінено цим Судом як очевидна відсутність законних підстав для усунення захисника, що привело до порушення ч. 3 (с) ст. 6 Конвенції. 


\begin{abstract}
Висновки
Підсумовуючи вищезазначене, можна зробити висновки, що посадові особи, які здійснюють досудове розслідування, зобов'язані забезпечити право особи обирати форму захисту самостійно, безперешкодно і запрошувати собі захисника, а у випадках матеріальної неспроможності, залучати захисника безоплатно. При цьому такі особи не несуть відповідальності за прорахунки та недоліки у діяльності залученого ними за призначенням захисника. Однак, у випадку виявлення фактів порушення права підозрюваного, обвинуваченого, засудженого та виправданого на професійну правничу допомогу або надходження від самого підозрюваного, обвинуваченого відповідного обгрунтованого клопотання, вони зобов'язані вживати відповідні заходи реагування, щодо ефективного забезпечення права на призначення іншого захисника. Запровадження європейських правових стандартів та удосконалення чинного законодавства, усунення неузгодженостей між окремими законами України з вказаних питань сприятиме швидкому, повному та неупередженому досудовому розслідуванню, що є одним iз завдань кримінального провадження(ст. 2 КПК України). Втім, підняті питання не $є$ остаточними і підлягають окремому дослідженню або науковому вивченню.
\end{abstract}

\section{Мiтература}

1. Конституція України від 28.06.1996 р. Відомості Верховної Ради Украйни. 1996.№. 30. Ст. 141.

2. Кримінальний процесуальний кодекс України від 13.04.2012 р.Відомості ВерховноїРади України (ВВР) 2013. № 9-10, № 1112, № 13, Ст.88.

3. Про адвокатуру та адвокатську діяльність : Закон України від 05.07.2012№ 5076-VI .Відомості Верховної Ради (ВВР). 2013. № 27. Ст. 282.

4. Основні принципи, що стосуються ролі юристів у кримінальному процесі, прийняті Конгресом ООН 27 серпня - 7 вересня 1990 року / [електронний ресурс] - http:// zakon3.rada.gov.ua/laws/show/995_313.

5.Международный пакт о гражданских и политических правах от16.12.1966 года. - [Электронный ресурс]. - Режим доступа:http://zakon4.rada.gov.ua/laws/ show/995_043

6. Конвенція про захист прав людини i основних свобод 1950 року / [електронний pecypc] - http://zakon1.rada.gov.ua/cgi-bin/ laws/main.cgi?nreg=995 004 .

7. Маляренко В.Т. Конституційні засади кримінального судочинства. Київ : Юрінком Інтер. 1999. 320 c.

8. Х.Аютер, А. Мужиновский, $\lambda$. Надь и др. Право обвиняемого на защиту в социалистическом уголовном процессе: практ. пособ. Под ред. и с предисл. В. М. Савицкого. Москва. 1983. С. 25.

9. Титов А. М. Основні принципи та особливості участі захисника на досудовому слідстві : монографія. Донецьк. Донецький юридичний інститут. 2005. 256 с.

10. Абламський С.Є. Дискусійні питання реалізації потерпілим права на захист за чинним кримінальним процесуальним законодавством України. Вісник ХНУВС. 2013.№1 (60). С. 46-51.

11. Власова Г. Деякі аспекти застосування Кримінального процесуального кодексу України у практичній діяльності. Актуальні питання кримінального процесуального законодавства України (Київ, 26 квітня 2013 року): збірник матеріалів міжвузівської наукової конференції. Національна академія прокуратури України. Київ. Алерта. 2013.C. 31-33.

12. Маланчук П. Окремі питання реалізації норм Кримінального процесуального кодексу України. Актуальні питання кримінального процесуального законодавства України (Київ, 26 квітня 2013 року): збірник матеріалів міжвузівської наукової конференції . Національна академія прокуратури України. Київ. Алерта. 2013. С. 51-55.

13. Рішення Європейського суду з прав людини у справі «Шабельник проти України» від 19 лютого 2009 року № 16404/03 [Електронний ресурс]. - Режим доступу: http://umdpl.info/index. php?id=1236239472.

14. Васильев Г. Новий Кримінальнопроцесуальний кодекс України: кого він захищатиме? Голос Украӥни. 2003. № 195. С. 6.

15. Про застосування законодавства, яке забезпечує право на захист у кримінально- 


\section{АНОТАЦІЯ}

у статті здійснено теоретичне дослідження законодавчих, наукових $і$ прикладних питань залучення захисника у кримінальному провадженні. При иъому проаналізовано різні наукові школи і позищї окремих науковиів щодо дослідженого напряму та матеріали правозастосовної практики,відноснояких висловлені власні наукові погляди автора. Внесено конкретні пропозищї щодо удосконалення окремих положень кримінального процесуального законодавства Украӥни та правозастосовної діяльності з досліджених питань.

Ключові слова: досудове розслідування, кримінальний прочес, право на захист, захисник, правова допомога, статус, положення, закон, процесуальні правовідносини, учасник, функиія, наукова позиція, слідчий, прокурор, слідчий суддя, права і свободи.

му судочинстві : Постанова Пленуму Верховного суду України від 24 жовтня 2003 р. № 8. - [Електронний ресурс]. - Режим доступу : http://zakon4.rada.gov.ua/laws/show/ v0008700-03.

16. Кучинська О.А. Кваліфікований захист як передумова реалізації права на справедливий суд. Академіяпрокуратури Украйни. 2011. № 1(10). С. 4-5.

17. Рішення Европейського суду 3 прав людини у справі «Яременко проти України» від 12 червня 2008 року, заява № 32092/02 [Електронний ресурс] - Peжим доступу: http://www.minjust.gov.ua/files/ Yaremenko_20091020.zip
The procedurebasis for the defence counsel (attorney) involvement to criminal proceedings

The article provides the theoretical study of legislative, scientific and practical issues of procedure basis and the mechanism of involving a defence counsel to criminal proceedings. The procedure mechanism for attracting a defence counsel according to the previous and current criminal procedure legislation of Ukraine and the position of the Supreme Court of Ukraine are investigated In a comparative aspect. In accordance with the results of the study, certain gaps, inconsistencies and flaws in the current criminal procedure legislation of Ukraine on certain issues have been identified.

Various scientific opinions of different scholars and scientific schools engaged in the specified areas in relation to the investigated issues and materials of law enforcement practice are analyzed, which results in the author's own scientific views. The study and analysis of the European Court of Human Rights practice as well as the expediency of initiating its decisions into the practice of law enforcement agencies and national courts are researched.

On the basis of the study, specific suggestions and recommendations have been provided to improve certain provisions of the criminal procedure legislation of Ukraine and practice in this area of investigatory bodies of pre-trial investigation, procedure heads in criminal proceedings of the prosecutor's office, investigators and judges of judicial bodies on investigated issues. According to the author's scientific opinion, the proposals and recommendations can help increase the efficiency of initiation and implementation the right to protect all participants in criminal proceedings at different stages of the criminal process.

Keywords: pre-trial investigation, criminal procedure, right to protection, defence counsel, legal aid, status, provisions, law, procedure legal relationship, member, function, scientific opinion, investigator, prosecutor,examining magistrate, rights and freedoms. 